\title{
APLIKASI EDUKASI TATA SURYA MENGGUNAKAN AUGMENTED REALITY BERBASIS MOBILE
}

\author{
Castaka Agus Sugianto \\ Program Studi Teknik Informatika \\ Politeknik TEDC Bandung \\ Jl. Politeknik-Pesantren KM2 Cibabat Cimahi Utara - Cimahi Jawa Barat - Indonesia \\ castakagpoltektedc.ac.id
}

\begin{abstract}
Abstrak - Seiring dengan perkembangan teknologi informasi yang terus bergerak dari tahun ke tahun, banyak metode pembelajaran yang diciptakan untuk mendukung proses belajar mengajar. Media pembelajaran berupa alat peraga pembelajaran tata surya saat ini masih menggunakan media cetak, video tutorial dan alat peraga sederhana lainnya di mana guru lebih dominan menerangkan dan siswa hanya menyimak. Metode seperti ini kurang mengasah kreatifitas dan daya tangkap siswa, ditambah penggunaan alat peraga yang terbatas, di sisi lain tersedianya teknologi terbaru yang dapat dikembangkan menjadi media pembelajaran. Metode pembelajaran dengan dukungan media yang menarik berbasis teknologi akan menciptakan pembelajaran yang efektif dan mencapai sasaran pembelajaran. Penerapan augmented reality dalam media pembelajaran tata surya bertujuan untuk memberikan inovasi metode pembelajaran yang dapat menciptakan komunikasi belajar yang interaktif antara guru dan siswa. Metode penelitian yang digunakan adalah metode Microsoft Solution Framework. Dalam proses pembuatan aplikasi ini, metode yang dipakai adalah metode spiral dimana aplikasi dikembangkan secara bertahap sampai dihasilkan aplikasi versi lengkap. Metode implementasi yaitu dengan mengimplementasikan Augmented Reality menggunakan Vuforia dan Unity untuk diaplikasikan pada perangkat Android. Hasil yang dicapai adalah sebuah aplikasi pengenalan tata surya yang menampilkan objek dan informasi. Dengan adanya aplikasi Augmented Reality tata surya berbasis Android ini dapat memberikan kemudahan untuk memvisualisasikan materi tata surya dalam bentuk pemodelan yang lebih nyata dilengkapi dengan Solar AR Book yang berisi rangkuman materi pendukung.
\end{abstract}

Kata kunci- augmented reality, media pembelajaran, tata surya, unity, vuforia, mobile android

\section{PENDAHULUAN}

\section{A. Latar Belakang}

Pembelajaran merupakan suatu proses yang dilakukan untuk mencapai kopetensi, di mana pembelajaran ini terjadi proses komunikasi antara peserta didik, pengajar dan bahan ajar. Komunikasi tidak akan berjalan dengan baik tanpa bantuan sarana penyampai pesan atau media. Pesan yang dikomunikasikan adalah isi pembelajaran yang dituangkan ke dalam simbol-simbol komunikasi baik simbol verbal maupun non verbal atau visual [1].

Dalam proses pembelajaran umumnya pengajar menggunakan alat bantu mengajar berupa gambar, model atau alat-alat lainnya yang diharapakan dapat memberikan pengalaman secara konkrit, motivasi belajar serta mempertinggi daya serap. Dalam menciptakan media pembelajaran dan materi yang semakin interaktif serta kmperhensif dunia pendidikan terus berbenah. Media yang digunakan pada umumnya tersedia antara lain : buku, jurnal, koran, radio, TV dan internet sebagai media online [2]

Dengan perkembangan teknologi saat ini yang semakin pesat, berbagai media pembelajaran mulai dikembangkan untuk membantu proses belajar mengajar. Hal ini diharapkan dapat menumbuhkan minat belajar dengan konsep yang lebih menarik dan mudah dipahami. Teknologi Augmented Reality merupakan salah satu teknologi yang berkembang saat ini. Teknologi yang menggabungkan dunia maya (virtual) dan dunia nyata (real) dalam waktu nyata di sebut Augmented Reality [3]. Di Indonesia, teknologi Augmented Reality tergolong baru dan sedang dikembangkan seperti untuk pembuatan game, simulasi, media pembelajaran dan lain-lain.

Untuk kemudahan pembelajaran, teknologi Augmented Reality ini juga dikembangkan dalam berbagai cabang ilmu pendidikan salah satunya pada cabang ilmu pengetahuan alam. Ilmu pengetahuan alam merupakan cabang ilmu yang mempelajari fenomena-fenomena alam, sehingga ilmu pengetahuan alam semakin menarik untuk dipelajari. Namun bagi segelintir pelajar, ilmu 
pengetahuan alam terutama yang berhubungan dengan teori fisika merupakan pelajaran yang sulit untuk dipahami. Metode pembelajaran konsep fisika yang disajikan selama ini monoton dan kurang menarik, siswa hanya diposisikan sebagai pendengar karena guru menerangkan materi terbatas pada alat peraga melalui media gambar dan simulasi sederhana sehingga minat siswa untuk mempelajarinya lebih rendah. Banyak siswa menyatakan bahwa pembelajaran fisika membosankan, hasil belajar siswa masih rendah, siswa sulit memahami konsep dalam pelajaran fisika [4]. Sehubungan dengan hal ini perlu adanya perubahan metode belajar dengan menyediakan media pembelajaran yang lebih interaktif.

Salah satu materi pembelajaran fisika yang menarik untuk dikembangkan menggunakan Augmented Reality adalah pembelajaran tata surya. Dimana telah diketahui bersama bahwa kumpulan benda langit yang terdiri dari matahari sebagai pusat tata surya dan benda langit yang terikat oleh gaya gravitasinya itulah tata surya. Penggabungan teknologi Augmented Reality dengan pembelajaran ilmu fisika khususnya pada materi tata surya dapat meningkatkan daya tangkap, imijinasi dan kemauan siswa, karena dikemas dalam bentuk yang menarik dengan tampilan gambar 3D yang menjadikan objek terlihat lebih nyata sehingga dapat mendorong proses belajar. Media buku atau video tutorial dirasa belum cukup efektif untuk bisa menyampaikan materi khususnya materi yang kompleks seperti tata surya [5].

Selain berbasis desktop, teknologi Augmented Reality ini juga sudah dipadukan dengan perangkat mobile. Hal ini tentunya lebih memberikan keefektifan dan ruang gerak yang lebih leluasa kepada penggunanya. Android sebagai salah satu sistem operasi smartphone yang handal dan selalu mengintegrasikan diri dengan berbagai teknologi terkini menjadikan Android semakin diminati berbagai kalangan. Terbukti dengan kehandalan Android dalam menjalankan fungsinya sebagai ponsel smart dalam menerapkan teknologi Augmented Reality di dalamnya.

Vuforia merupakan Library Augmented Reality untuk perangkat mobile yang digunakan untuk pembuatan aplikasi Augmented Reality di Unity3D. SDK Vuforia memiliki keunggulan karena mendukung berbagai jenis target 2D dan 3D. Selain itu Vuforia kompatibel dengan berbagai perangkat mobile termasuk iPhone, iPad Android dan tablet. Dengan teknologi Vuforia dari Qualcomm, developer Augmented Reality dapat menciptakan beragam teknologi yang memiliki value tinggi mulai dari game, aplikasi, iklan, presentasi dan lainnya [6].

Untuk membangun aplikasi Augmented Reality dengan menggunakan SDK Vuforia, penulis menggunakan aplikasi Unity3D. Unity $3 D$ merupakan aplikasi yang diigunakan untuk mengembangkan game multi platform yang didesain untuk mundah digunakan. Unity secara rinci dapat digunakan untuk membuat video game $3 \mathrm{D}$, real time animasi 3D dan visualisasi arsitektur. Merupakan game engine yang bersifat open source serta memiliki tools yang bermanfaat dalam pembuatan game dan aplikasi real time seperti tools untuk randering, library physics, sound dan lainnya. [7].

Berdasarkan latar belakang di atas, penulis merumuskan permasalah sebagai berikut:

1. Bagaimana menumbuhkan minat belajar melalui media pembelajaran yang lebih menarik dan mudah dipahami?

2. Bagaimana menerapkan metode pembelajaran yang interaktif antara guru dan siswa?

3. Bagaimana membangun aplikasi pembelajaran tata surya menggunakan teknologi Augmented Reality berbasis Android untuk menunjang proses belajar siswa?

Adapun Tujuan penelitian adalah sebagai berikut:

1. Menumbuhkan minat belajar melalui alat bantu mengajar yang lebih menarik dan mudah dipahami.

2. Menerapkan metode pembelajaran yang interaktif antara guru dan siswa.

3. Membangun aplikasi pembelajaran tata surya menggunakan teknologi Augmented Reality berbasis Android untuk menunjang proses belajar siswa.

\section{LANDASAN TEORI}

\section{A. Media Pembelajaran}

Pembelajaran atau learning merupakan proses yang dilakukan untuk mencapai sasaran belajar di mana terjadi proses komunikasi antara peserta didik , pengajar dan bahan ajar. Komunikasi ini tidak akan berjalan tanpa bantuan sarana penyampai pesan atau media. Pesan yang 
dikomunikasikan adalah isi pembelajaran yang dituangkan ke dalam simbol-simbol komunikasi baik simbol verbal maupun non verbal atau visual [1].

Dalam proses pembelajaran biasanya menggunakan alat bantu mengajar berupa gambar, model atau alat-alat lainnya yang dapat memberikan pengalaman konkrit, motivasi belajar serta mempertinggi daya serap. Dunia pendidikan terus bergerak secara dinamis, khususnya untuk menciptakan media, metode dan materi yang semakin interaktif dan komperhensif. Media yang secara lazim tersedia antara lain : buku, jurnal, koran, radio, TV dan internet sebagai media online.

\section{B. Augmented Reality}

Menurut [3], Augmented Reality (AR) merupakan teknologi yang menggabungkan antara dunia maya (virtual) dan dunia nyata (real) dalam waktu yang nyata yang dibuat oleh komputer. Obyek virtual yang digabungkan dengan lingkungan sebenarnya bisa berupa teks, animasi, model 3D atau video sehingga user dapat merasakan obyek virtual seolah-olah berada dilingkungan yang nyata. Kerangka kerja Augmented Reality digambarkan seperti pada gambar 1 .

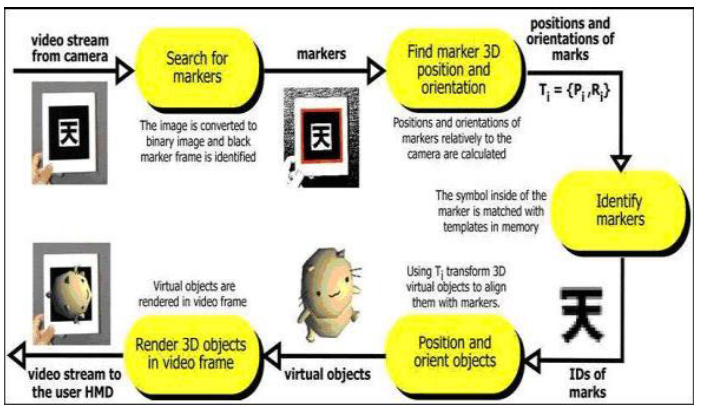

Gambar 1. Kerangka Kerja Augmented Reality [15]

Lingkungan nyata disekitar kita akan dapat di gabungakan dengan dunia virtual menggunakan bantuan teknologi Augmented Reality. Teknologi Augmented Reality dapat menambahkan informasi-informasi tentang obyek dan lingkungan disekitar kita yang kemudian informasi tersebut ditampilkan diatas Layar dunia nyata secara real-time seolah-olah informasi atau obyek tersebut adalah nyata[8].

\section{Penggunaan dan Pengembangan Aplikasi Augmented Reality}

Secara sederhana, perangkat keras yang diperlukan dalam pengembangan aplikasi Augmented Reality dapat dikelompokkan menjadi [10] :

1. Unit visualisasi, merupakan perangkat yang akan menampilkan objek 2D, 3D atau tampilan video dari aplikasi Augmented Reality. Alat yang temasuk dalam unit visualisasi adalah HMD, monitor dan screen projector.

2. Unit pemrosesan, merupakan unit yang memiliki kemampuan untuk memproses semua layanan yang dibutuhkan oleh unit visualisasi dan unit intreaksi yang terhubung

$$
\text { Gambar 2. Contoh Fiducial Marker [16] } \cdots
$$

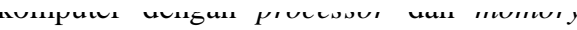
yang cukup untuk menjalankan aplikasi Augmented Reality.

3. Unit interaksi, dapat berupa mouse, keyboard atau handmarker.

Terdapat beberapa media yang dapat digunakan untuk melihat Augmented Reality, yaitu PC Monitor/TV, Handphone, Goggles dan Contact Lens. Selain perangkat keras ini, terdapat juga perangkat pendukung tambahan seperti perangkat audio, sistem tata pencahayaan untuk mendukung unit visualisasi dan lain sebagainya sesuai kebutuhan.

\section{Marker Augmented Reality}

Saat ini sudah banyak penelitian tentang marker untuk keperluan Augmented Reality [10]. Gambar 2 merupakan marker matrix atau fiducial marker, marker ini tampilanya sederhana dan dapat bekerja dengan sangat baik. Untuk mengenali sebuah objek, Fiducial marker menggunakan barcode 2D.

\section{Fiducial Marker}

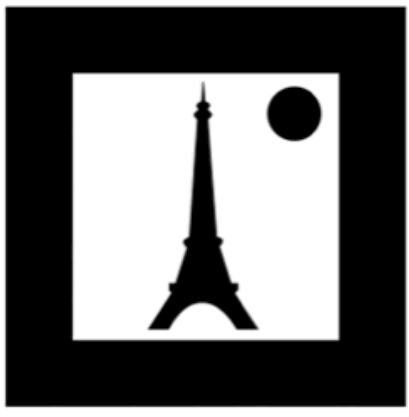

Gambar 2. Contoh Fiducial Marker [16] 
Marker berwarna hitam putih yang bentuknya kotak dengan border sangat tebal. Fiducial Marker merupakan marker yang polanya paling mudah dikenali secara visual serta bentuknya yang sangat merepresentasikan marker pada Augmented Reality. Gambar 2. berikut merupakan contoh fiducial marker dalam Augmented Reality.

\section{Marker Texture atau Surface}

Cara kerja Marker-Texture adalah dengan megidentifkasi pola-pola tertentu pada suatu permukaan (surface) gambar. Secara visual, marker ini lebih menarik karena dapat mengenali pola berupa foto atau gambar. Tetapi marker jenis ini lebih sulit dikenali secara visual. Karenanya diperlukan pola gambar yang memiliki texture tinggi. Gambar 3 di bawah ini merupakan contoh penggunaan MarkerTexture.

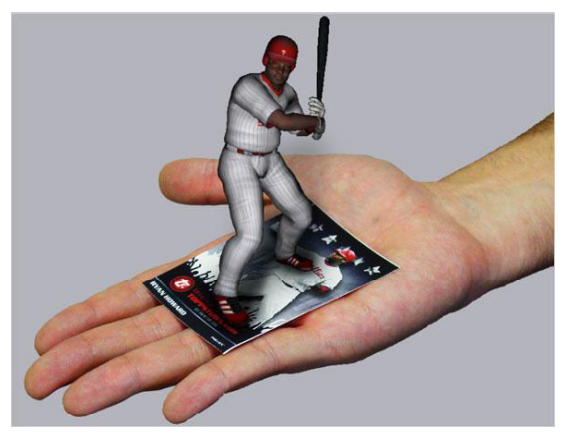

Gambar 3. Contoh Marker-Texture [17]

Metode Markerless Augmented Reality merupakan metode untuk menampilkan Augmented Reality yang saat ini sedang berkembang, dengan metode markerless ini untuk menampilkan objek 3D tidak perlu lagi menggunakan sebuah marker. Perusahaan Augmented Reality terbesar di dunia Total Immersion dan Qualcomm, telah menerapkanya, adapun jenis metode markerless sebagai berikut: Face Tracking, 3 D Object Tracking, dan Motion Tracking [11].

\section{E. Tata Surya}

Tata Surya adalah benda-benda langit yang terikat oleh gaya graitasi yang terdiri dari sebuah bintang besar yang disebut matahari sebagai pusatnya. Benda langit tersebut adalah delapan buah planet yang sudah diketahui (Merkurius, Venus, Bumi, Mars, Jupiter, Saturnus, Uranus, dan Neptunus) dengan orbit berbentuk elips, jutaan benda langit (Meteor, asteroid, komet), 173 satelit alami yang diidentifikasi, dan5 planet kerdil lainnya. Keluarga matahari (The sun and it's family) atau sering disebuat sebagai tata surya (solar system).[12].

\section{F. Android}

Android adalah sistem operasi yang terdapat pada telepon selular seperti smartpohone dan tablet sistem oprasi ini berbasis linux. Android merupakan platform open source yang mengijinkan bagi para pengembang untuk membuat aplikasi mereka sendiri. Android Inc yang awalnya di beli Google Inc. pendantang baru yang membuat software untuk ponsel. Pembentukan Open Handset Allience yang bertujuan untuk mengembangkan Andoid, 34 konsorium perusahaan telekomunikasi, Software dan Hardware, termasuk Google, Intel, HTC, Motorola, Nvidia, T-Mobile dan Qualcomm. Perilisan perdana yang dilakukan pada 5 November 2007. Open Handset Allience yang mengembangkan Andoid pada perangkat Mobile mendukung adanya pengembangan standar terbuka[13].

\section{G. Vuforia}

Vuforia merupakan plugin yang digunakan uıtuk membangun aplikasi Augmented Reality yang dikembangkan oleh Qualcomm. Platform Vuforia mendukung para pengembang untuk mengembangkan aplikasi yang dapat digunakan di hampir seluruh jenis smartphone dan tablet seperti iOS dan Android. Pengembang aplikasi juga dapat mendesain dan membuat aplikasi, dengan kemampuan sebagai berikut:

1. Teknologi penglihatan komputer yang mengijinkan pengembang untuk menciptakan efek khusus pada mobile device.

2. Dapat mengenali beberapa gambar sekaligus.

3. Pelacakan dan deteksi tingkat lanjut.

4. Seting basis data gambar yang cukup fleksibel. 
1) Vuforia API Reference:

API reference berisikan informasi mengenai hirarki kelas dan fungsi member dari $Q C A R$ SDK. Sistem dari $Q C A R S D K$ menyediakan : callback event contoh sebuah image baru yang tersedia.

1. High-level access ke perangkat keras contohnya kamera start/stop.

2. Multiple trackables

3. Interaksi secara langsung dengan dunia nyata

\section{2) Arsitektur Vuforia}

Vuforia SDK memerlukan beberapa komponen penting agar dapat bekerja dengan baik [8], diantaranya :

1. Kamera

2. Image Converter

3. Tracker

4. Video Background Randerer

5. Application code

6. Target Resources

\section{3) Metode Pengenalan Gambar}

Qualcomm melakukan proses pendeteksian marker menggunakan metode pengenalan pola gambar. Natural Features Tracking adalah metode yang di gunakan oleh Qualcomm Augmented reality. Natural Features Tracking menggunakan teknik FAST Corner Detection. Cara kerjanya dengan mencari titik-titik atau sudut-sudut pada suatu gambar. Sedangkan untuk mendapatkan pendeteksian sudut secara cepat dilakukan teknik pendeteksian tepi. Kemudian FAST corner detection mengalami perkembangan sehingga teknik pendeteteksian tepi tidak lagi di gunakan[8].

\section{H. Unity3D}

Unity3D merupakan suatu aplikasi yang digunakan untuk mengembangkanUnity $3 D$ adalah salah satu software yang digunakan untuk membangun game multi-platform, atau disebut juga game engine. Unity menjadi ranking teratas di deretan Editor game dikarenakan unity memiliki user interface yang sederhana dan grafis Unity mengunakan teknologi OpenGL dan DirectX. Unity juga memiliki keemampuan yang didukung semua format file[7].

\section{III.PEMBAHASAN}

\section{A. Analisis Sistem yang Sedang Berjalan}

Metode pembelajaran materi tata surya yang diterapkan saat ini sebagian besar masih bersifat monoton dimana guru menerangkan dan siswa menyimak. Pemaparan materi tata surya dilakukan dengan bantuan media cetak seperti buku dan gambar-gambar serta penggunaan video untuk mempresentasikan materi tentang tata surya.

Metode pembelajaran yang diterapkan pada umumnya kurang membangkitkan minat siswa untuk belajar dan mendorong kreatifitas serta imajinasi siswa. Apalagi materi fisika tentang tata surya ini merupakan materi yang sangat kompleks dan memerlukan daya imajinatif yang tinggi.

\section{B. Analisis Sistem yang Dikembangkan}

Aplikasi Augmented Reality pembelajaran tata surya ini akan memberikan kemudahan bagi guru dan siswa dalam mempelajari materi tata surya. Aplikasi ini akan disertakan dengan Solar AR Book yang berisi informasi tentang tata surya beserta marker untuk menampilkan objek Augmented Reality tata surya.

Aplikasi terlebih dahulu diinstal di device Android guru dan siswa kemudian aplikasi di dijalankan sesuai pilihan menu yang ada. Ketika tombol start di jalankan, user akan diarahkan ke kamera AR camera yang selanjutnya diarahkan ke marker yang tersedia pada Solar AR Book lalu objek 3D dan informasi tata surya akan muncul seperti pada gambar 4. dibawah.

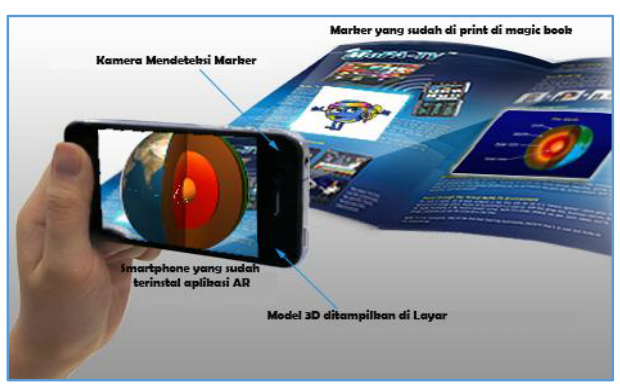

Gambar 4. llustrasi Sistem yang Akan Dikembangkan 
C. Analisis Kebutuhan Sistem

Aplikasi yang dikembangkan ini merupakan aplikasi berbasis mobile yang di jalankan pada perangkat smartphone Android. Pembuatan aplikasi ini membutuhkan komponen hardware, software, brainware dan kebutuhan fungsional lainnya untuk dapat dijalankan dengan baik pada perangkat smartphone Android.

\section{1) Kebutuhan Hardware}

Dalam pembuatan aplikasi Augmented Reality, perangkat keras untuk membangun aplikasi akan sangat mempengaruhi hasil aplikasi yang dibuat. Spesifikasi minimal hardware adalah sebagai berikut [5]:

1. PC atau Laptop dengan processor Core 2 Duo

2. Random Access Memory (RAM) $2 \mathrm{~Gb}$

3. Harddisk dengan ruang kosong $500 \mathrm{Mb}$

4. VGA HD Graphics $1 \mathrm{~Gb}$

5. Camera Webcam 1.3 MP

Adapun spesifikasi hardware device untuk menjalankan aplikasi Augmented Reality pada perangkat Android adalah sebagai berikut [14] :

1. Device Android minimal OS Ginger Bread

2. Processor dengan arsitektur ARM (Advance RISC Machine) Versi 7 (ARMV7)

3. Kapasitas RAM minimal $512 \mathrm{Mb}$

4. Kamera 2 MP

Support OpenGL ES 2.0

\section{2) Kebutuhan Software}

Pembuatan aplikasi ini menggunakan beberapa software sebagai berikut :

1. Microsoft Windows 7 Ultimate 32-bit

2. Autodesk 3DS Max 2010

3. Unity 4.3.2.f1

4. Adobe Photoshop CS3

D. Perancangan

1) Flowchart Aplikasi AR

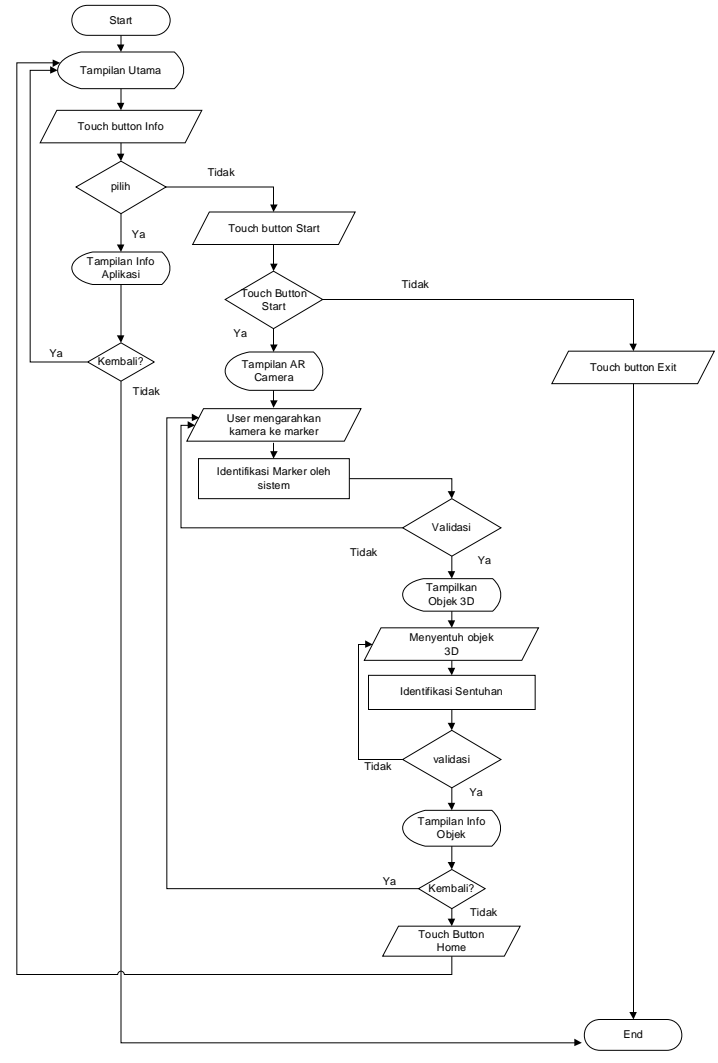

Gambar 5. Flowchart Aplikasi AR

2) Use Case Aplikasi AR

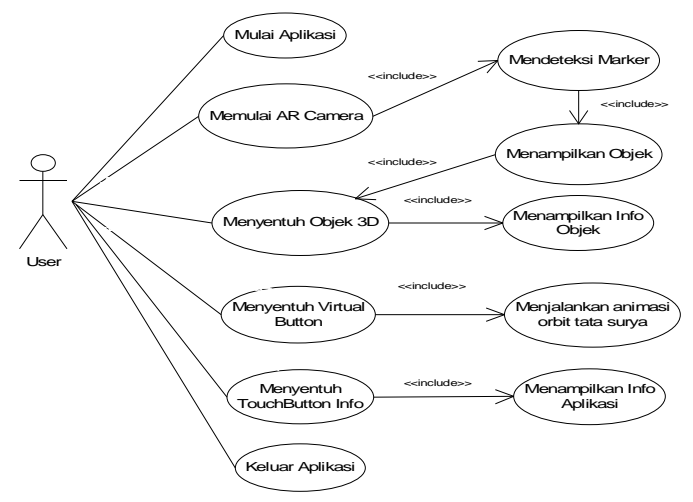

Gambar 6. Use Case Aplikasi AR 
3) Perancangan Marker

Tabel 1. Daftar Marker yang Digunakan

\begin{tabular}{|c|c|c|}
\hline No & $\begin{array}{c}\text { Nama } \\
\text { Komponen }\end{array}$ & Gambar Marker \\
\hline 1. & Tata Surya & \\
\hline 2. & Matahari & \\
\hline 3. & Merkurius & \\
\hline 4. & Venus & \\
\hline 5. & Bumi & \\
\hline 6. & Mars & \\
\hline 7. & Saturnus & \\
\hline 8. & Uranus & \\
\hline
\end{tabular}

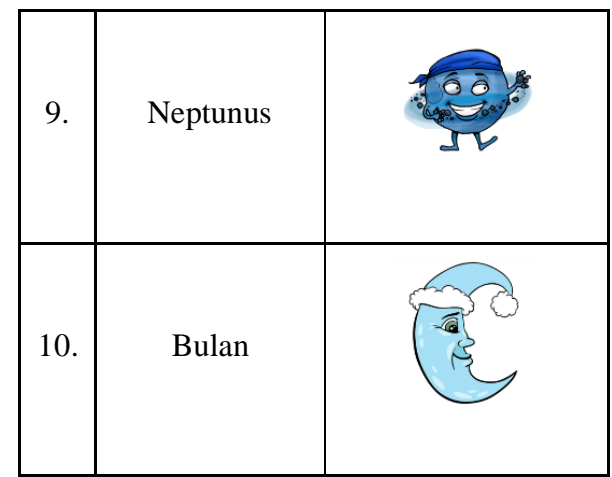

E. Implementasi Sistem

Pada tahapan implementasi untuk membangun sebuah aplikasi Augmented Reality ini maka ada beberapa kebutuhan sistem yang harus terlebih dahulu dipenuhi.

1) Load Library Vuforia pada Unity

Untuk mengembangkan aplikasi Augmented Reality pada unity, maka terlebih dahulu harus melakukan load library vuforia unity yang bisa di download pada website Vuforia. Setelah di download, library tersebut diimport ke dalam project unity yang telah dibuat agar pembuatan aplikasi Augmented Reality dapat berjalan dengan baik.

\section{2) Menampilkan Marker}

Dalam membangun aplikasi Augmented Reality Marker merupakan salah satu komponen yang cukup penting. Oleh karena itu dalam pembuatan marker harus benar-benar memenuhi syarat marker yang baik menurut kriteria vuforia.

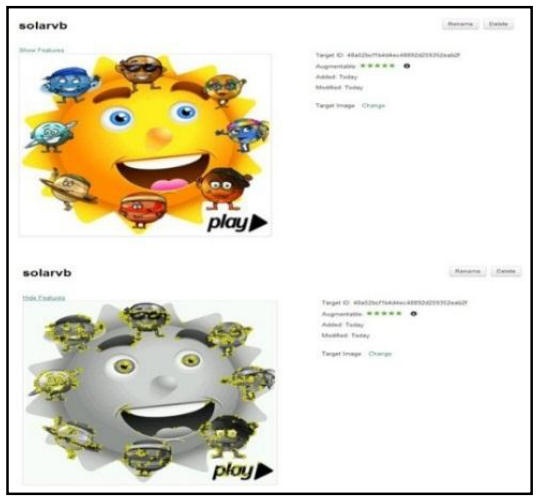




\section{F. Menampilkan Objek $3 D$}

Objek 3D akan muncul pada layar device ketika AR camera diarahkan tepat di atas marker dan sistem berhasil memvalidasi marker tersebut. Gambar 8. merupakan salah satu tampilan aplikasi augmented reality tata surya yang berhasil menampilkan objek 3D.

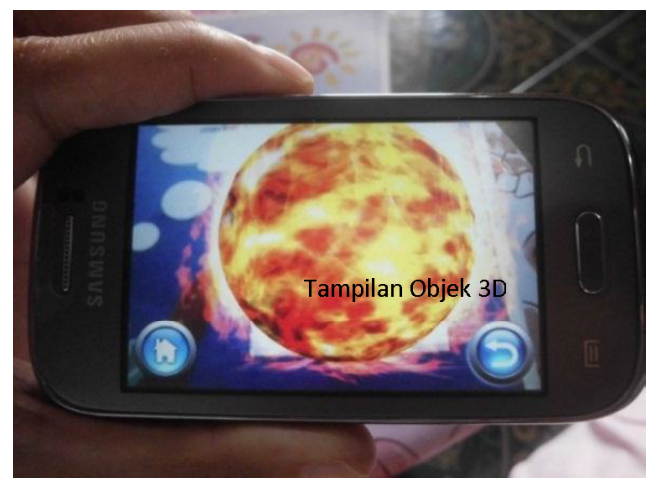

Gambar 8. Tampilan Objek 3D

\section{G. Pengujian Sistem}

1. Pengujian berdasarkan kondisi cahaya dan jarak dapat dilihat pada tabel 2 dan tabel 3 berikut ini. Pengujian berdasarkan kondisi cahaya dilakukan dalam ruangan berukuran $7.5 \mathrm{~m}^{2}$ dengan sumber pencahayaan lampu neon jari (putih).

Tabel 1. Hasil Pengujian Kondisi Cahaya Terhadap Marker

\begin{tabular}{|l|c|c|c|}
\hline \multirow{2}{*}{$\begin{array}{l}\text { Marker yang } \\
\text { Diuji }\end{array}$} & \multicolumn{3}{|c|}{ Hasil pengujian dengan daya lampu: } \\
\cline { 2 - 4 } Tata Surya & $\begin{array}{c}\text { Tidak } \\
\text { Tedeteksi }\end{array}$ & $\begin{array}{c}\text { Berhasil } \\
\text { Terdeteksi }\end{array}$ & $\begin{array}{c}\text { Tidak } \\
\text { terdeteksi }\end{array}$ \\
\hline Matahari & $\begin{array}{c}\text { Tidak } \\
\text { Tedeteksi }\end{array}$ & $\begin{array}{c}\text { Berhasil } \\
\text { Terdeteksi }\end{array}$ & $\begin{array}{c}\text { Tidak } \\
\text { terdeteksi }\end{array}$ \\
\hline Merkurius & $\begin{array}{c}\text { Tidak } \\
\text { Tedeteksi }\end{array}$ & $\begin{array}{c}\text { Berhasil } \\
\text { Terdeteksi }\end{array}$ & $\begin{array}{c}\text { Tidak } \\
\text { terdeteksi }\end{array}$ \\
\hline Venus & $\begin{array}{c}\text { Tidak } \\
\text { Tedeteksi }\end{array}$ & $\begin{array}{c}\text { Berhasil } \\
\text { Terdeteksi }\end{array}$ & $\begin{array}{c}\text { Tidak } \\
\text { terdeteksi }\end{array}$ \\
\hline Bumi & $\begin{array}{c}\text { Tidak } \\
\text { Tedeteksi }\end{array}$ & $\begin{array}{c}\text { Berhasil } \\
\text { Terdeteksi }\end{array}$ & $\begin{array}{c}\text { Tidak } \\
\text { terdeteksi }\end{array}$ \\
\hline Mars & $\begin{array}{c}\text { Tidak } \\
\text { Tedeteksi }\end{array}$ & $\begin{array}{c}\text { Berhasil } \\
\text { Terdeteksi }\end{array}$ & $\begin{array}{c}\text { Tidak } \\
\text { terdeteksi }\end{array}$ \\
\hline Jupiter & $\begin{array}{c}\text { Tidak } \\
\text { Tedeteksi }\end{array}$ & $\begin{array}{c}\text { Berhasil } \\
\text { Terdeteksi }\end{array}$ & $\begin{array}{c}\text { Tidak } \\
\text { terdeteksi }\end{array}$ \\
\hline
\end{tabular}

\begin{tabular}{|l|c|c|c|}
\hline Saturnus & $\begin{array}{c}\text { Tidak } \\
\text { Tedeteksi }\end{array}$ & $\begin{array}{c}\text { Berhasil } \\
\text { Terdeteksi }\end{array}$ & $\begin{array}{c}\text { Tidak } \\
\text { terdeteksi }\end{array}$ \\
\hline Uranus & $\begin{array}{c}\text { Tidak } \\
\text { Tedeteksi }\end{array}$ & $\begin{array}{c}\text { Berhasil } \\
\text { Terdeteksi }\end{array}$ & $\begin{array}{c}\text { Tidak } \\
\text { terdeteksi }\end{array}$ \\
\hline Neptunus & $\begin{array}{c}\text { Tidak } \\
\text { Tedeteksi }\end{array}$ & $\begin{array}{c}\text { Berhasil } \\
\text { Terdeteksi }\end{array}$ & $\begin{array}{c}\text { Tidak } \\
\text { terdeteksi }\end{array}$ \\
\hline Bulan & $\begin{array}{c}\text { Tidak } \\
\text { Tedeteksi }\end{array}$ & $\begin{array}{c}\text { Berhasil } \\
\text { Terdeteksi }\end{array}$ & $\begin{array}{c}\text { Tidak } \\
\text { terdeteksi }\end{array}$ \\
\hline
\end{tabular}

Tabel 2. Pengujian Jarak Kamera terhadap Marker

\begin{tabular}{|c|c|c|c|}
\hline \multirow{2}{*}{$\begin{array}{l}\text { Marker yang } \\
\text { Diuji }\end{array}$} & \multicolumn{3}{|c|}{ Jarak } \\
\hline & $\angle 8 \mathrm{~cm}$ & $8-30 \mathrm{~cm}$ & $>30 \mathrm{~cm}$ \\
\hline Tata Surya & $\begin{array}{c}\text { Tidak } \\
\text { Tedeteksi }\end{array}$ & $\begin{array}{c}\text { Berhasil } \\
\text { Terdeteksi }\end{array}$ & $\begin{array}{c}\text { Tidak } \\
\text { Terdeteksi }\end{array}$ \\
\hline Matahari & $\begin{array}{c}\text { Tidak } \\
\text { Tedeteksi }\end{array}$ & $\begin{array}{c}\text { Berhasil } \\
\text { Terdeteksi }\end{array}$ & $\begin{array}{c}\text { Tidak } \\
\text { Terdeteksi }\end{array}$ \\
\hline Merkurius & $\begin{array}{c}\text { Tidak } \\
\text { Tedeteksi }\end{array}$ & $\begin{array}{c}\text { Berhasil } \\
\text { Terdeteksi }\end{array}$ & $\begin{array}{c}\text { Tidak } \\
\text { Terdeteksi }\end{array}$ \\
\hline Venus & $\begin{array}{c}\text { Tidak } \\
\text { Tedeteksi }\end{array}$ & $\begin{array}{c}\text { Berhasil } \\
\text { Terdeteksi }\end{array}$ & $\begin{array}{c}\text { Tidak } \\
\text { Terdeteksi }\end{array}$ \\
\hline Bumi & $\begin{array}{c}\text { Tidak } \\
\text { Tedeteksi }\end{array}$ & $\begin{array}{c}\text { Berhasil } \\
\text { Terdeteksi }\end{array}$ & $\begin{array}{c}\text { Tidak } \\
\text { Terdeteksi }\end{array}$ \\
\hline Mars & $\begin{array}{c}\text { Tidak } \\
\text { Tedeteksi }\end{array}$ & $\begin{array}{c}\text { Berhasil } \\
\text { Terdeteksi }\end{array}$ & $\begin{array}{c}\text { Tidak } \\
\text { Terdeteksi }\end{array}$ \\
\hline Jupiter & $\begin{array}{c}\text { Tidak } \\
\text { Tedeteksi }\end{array}$ & $\begin{array}{c}\text { Berhasil } \\
\text { Terdeteksi }\end{array}$ & $\begin{array}{c}\text { Tidak } \\
\text { Terdeteksi }\end{array}$ \\
\hline Saturnus & $\begin{array}{c}\text { Tidak } \\
\text { Tedeteksi }\end{array}$ & $\begin{array}{c}\text { Berhasil } \\
\text { Terdeteksi }\end{array}$ & $\begin{array}{c}\text { Tidak } \\
\text { Terdeteksi }\end{array}$ \\
\hline Uranus & $\begin{array}{c}\text { Tidak } \\
\text { Tedeteksi }\end{array}$ & $\begin{array}{c}\text { Berhasil } \\
\text { Terdeteksi }\end{array}$ & $\begin{array}{c}\text { Tidak } \\
\text { Terdeteksi }\end{array}$ \\
\hline Neptunus & $\begin{array}{c}\text { Tidak } \\
\text { Tedeteksi }\end{array}$ & $\begin{array}{l}\text { Berhasil } \\
\text { Terdeteksi }\end{array}$ & $\begin{array}{c}\text { Tidak } \\
\text { Terdeteksi }\end{array}$ \\
\hline Bulan & $\begin{array}{c}\text { Tidak } \\
\text { Tedeteksi }\end{array}$ & $\begin{array}{l}\text { Berhasil } \\
\text { Terdeteksi }\end{array}$ & $\begin{array}{c}\text { Tidak } \\
\text { Terdeteksi }\end{array}$ \\
\hline
\end{tabular}

Tabel VII. Hasil Pengujian berdasarkan Resolusi Layar Device

\begin{tabular}{|c|c|c|}
\hline \multirow{2}{*}{$\begin{array}{c}\text { Resolusi Layar } \\
\text { (Portrait / } \\
\text { Landscape) }\end{array}$} & \multicolumn{2}{|c|}{ Hasil sesuai orientasi layar } \\
\hline & Portrait & Landscape \\
\hline $\begin{array}{c}\text { HVGA } \\
(320 \times 480 / \\
480 \times 320)\end{array}$ & $\begin{array}{l}\text { Tampilan } \\
\text { Tidak } \\
\text { Sempurna }\end{array}$ & $\begin{array}{c}\text { Tampilan } \\
\text { Menyesuaikan } \\
\text { Layar }\end{array}$ \\
\hline $\begin{array}{c}\text { WVGA } \\
(480 \times 800 / \\
800 \times 480) \\
\end{array}$ & $\begin{array}{l}\text { Tampilan } \\
\text { Tidak } \\
\text { Sempurna }\end{array}$ & $\begin{array}{c}\text { Tampilan } \\
\text { Menyesuaikan } \\
\text { Layar }\end{array}$ \\
\hline
\end{tabular}




\begin{tabular}{|c|c|c|}
\hline FWVGA & Tampilan & Tampilan \\
$(480 \times 854 /$ & Tidak & Menyesuaikan \\
$854 \times 480)$ & Sempurna & Layar \\
\hline WSVGA & Tampilan & Tampilan \\
$(600 \times 1024$ & Tidak & Menyesuaikan \\
/1024x600) & Sempurna & Layar \\
\hline WXGA & Tampilan & Tampilan \\
$(800 \times 1280 /$ & Tidak & Menyesuaikan \\
1280x800) & Sempurna & Layar \\
\hline
\end{tabular}

Berdasarkan hasil pengujian dan analisis terhadap hasil pengujian dapatdisimpulkan sebagai berikut:

1. Ketika menjalankan aplikasi, hal utama yang diperhatikan adalah waktu loading model. Semakin besar kapasitas objek dan banyaknya material maka semakin lama waktu loading objek.

2. Cahaya berpengaruh besar terhadap proses rendering objek. AR camera tidak bisa mengenali marker dalam keadaan gelap begitu juga jika terlalu terang. Kondisi cahaya yang terlalu terang akan menghasilkan pantulan pada marker sehingga node pada marker tidak dapat dideteksi kamera.

3. Visualisasi objek pada layar device dipengaruhi oleh jarak kamera terhadap marker. Marker terdeteksi dengan baik ketika marker berada dijarak yang dekat, tetapi jarak yang terlalu dekat atau miring terhadap marker membuat marker tidak berada dalam range kamera secara keseluruhan sehingga tidak akan memunculkan objek. Begitu pula dengan jarak yang terlalu jauh. Nilai toleransi jarak yang diharapkan antara kamera dengan marker adalah $8 \mathrm{~cm}$ sampai $30 \mathrm{~cm}$.

4. Marker yang terhalang secara langsung oleh benda maupun hal lain maka marker tidak akan dikenali oleh sistem.

5. Aplikasi Augmented Reality Tata Surya berjalan dengan baik pada berbagai resolusi device dengan orientasi layar landscape.

6. Hasil dari User Acceptance Test (UAT) menunjukkan skor mencapai $86.30 \%$ itu merupakan hasil yang sangat baik.

\section{IV.KESIMPULAN}

\section{A. Kesimpulan}

Berdasarkan dari hasil pengujian dan analisis pada penelitian ini maka diambil beberapa kesimpulan sebagai berikut:

1. Aplikasi Augmented Reality Tata Surya ini cocok dijadikan media pembelajaran dan alat peraga pengenalan tata surya untuk siswa tingkat Sekolah Dasar.

2. Aplikasi dalam bentuk mobile ini dapat mudah diimplementasikan oleh guru dan juga siswa sehingga aplikasi media pembelajaran ini dapat menciptakan suasana belajar yang lebih interaktif dan menyenangkan.

3. Media pembelajaran Augmented Reality ini dikemas dalam bentuk yang menarik yang bisa menampilkan gambar 3D menjadikan objek terlihat lebih nyata oleh karenanya dapat meningkatkan daya tangkap dan imijinasi sehingga dapat menunjang proses belajar mengajar.

\section{DAFTAR ISI}

[1] W. . Santyasa, "Landasan Konseptual Media Pembelajaran," pp. 1-23, 2007.

[2] P. Agung, "Pengembangan Bahan Pembelajaran mandiri Komputasi Fisika menggunakan 'moodle' secara online di Jurusan Fisika Universitas Negeri Semarang," 2006.

[3] B. . Suryawinata, "Pemanfaatan Augmented Reality Dalam Memvisualisasikan Produi Melalui Internet," 2010.

[4] R. Komala, "Implementasi Model Pembelajaran Novick sebagai Upaya Untuk meningkatkan Pemahaman Konsep Fisika Siswa SMKN," Skripsi Sarjana FPMIPA UPI Bandung, 2008.

[5] D. Prihantono, Aplikasi 3D Interaktif Tata Surya Berbasis Teknologi Augmented Reality. Surakarta: Buku AR Online, 2012.

[6] I. A. Tarigan, "5 Alasan mMengeksplorasi Game dengan Vuforia Apps," Chip Online, 2012. . 
[7] Hermantolle, "Unity 3D - Game Engine," 2013. .

[8] M. F. Rentor, Membangun AR Android Dengan Vuforia dan Unity. Surakarta: Buku AR Online, 2013.

[9] L. Saphiro and G. Stockman, "Sample of Computer Vision," 2000.

[10] D. Susandi, "Pemanfaatan AR sebagai Media Pembelajaran Pengenalan Bangun Ruang Menggunakan Artoolkit," Politeknik TEDC Bandung, 2013.

[11] L. Senja, "Augmented Reality: Masa Depan Interaktivitas," 2012.

[12] nationalgeographic, "Solar System," 2013.

[13] R. Henri, "Pengembangan Aplikasi Android," 2013, p. 2.

[14] T. Domhan, "Augmented Reality on Android Smartphones Zusammenfassung," 2010.
[15] R. Chandra and J. Kristama, "Augmented Reality Untuk Panduan Museum Berbasis Android Menggunakan Frame marker," Bina Nusantara University, 2012.

[16] M. Brew, "Future Potential of Technology," 2009. .

[17] Jhon, "Augmented Reality (AR) Technology," 2011. . 